\title{
DIVERSITY AND BIOMASS OF CHIRONOMIDAE (DIPTERA) LARVAE IN AN IMPACTED COASTAL LAGOON IN RIO DE JANEIRO, BRAZIL
}

\author{
CALLISTO, M., ${ }^{1}$ MORENO, P., ${ }^{1}$ GONÇALVES, J. F. Jr., ${ }^{2}$ \\ LEAL, J. J. F. ${ }^{2}$ and ESTEVES, F. A. ${ }^{2}$ \\ ${ }^{1}$ Universidade Federal de Minas Gerais, ICB, Depto. Biologia Geral, Lab. Limnologia/Ecologia de Bentos, C.P. 486, \\ CEP 30161-970, Belo Horizonte, MG, Brazil \\ ${ }^{2}$ Universidade Federal do Rio de Janeiro, CCS, IB, Depto. Ecologia, Lab. Limnologia, \\ CEP 21941-540, Rio de Janeiro, RJ, Brazil \\ Correspondence to: Marcos Callisto, Universidade Federal de Minas Gerais, ICB, Depto. Biologia Geral, \\ Laboratório de Limnologia/Ecologia de Bentos, C.P. 486, CEP 30161-970, Belo Horizonte, MG, Brazil, \\ e-mail: callisto@mono.icb.ufmg.br \\ Received October 9, 2000 - Accepted January 8, 2001 - Distributed February 28, 2002
}

\begin{abstract}
Diversity and biomass of Chironomidae larvae were studied between January-November 1993 and MarchNovember 1994 in an impacted lagoon in Rio de Janeiro, Southeastern Brazil, in an attempt to establish the ecological consequences of anthropogenic eutrophication processes. Nine hundred and seventyfive organisms belonging to the Tanypodinae, Orthocladiinae, and Chironominae were collected. Polypedilum (62\%) and Chironomus (58\%) were the most common genera found in the limnetic and littoral zones.
\end{abstract}

Key words: biodiversity, eutrophication, chironomids, bioindicators, coastal lagoon.

\section{RESUMO}

\section{Diversidade e biomassa de larvas de Chironomidae (Diptera) em uma lagoa costeira impactada no Estado do Rio de Janeiro, Brasil}

Foram estudadas a diversidade e a biomassa de larvas de Chironomidae entre janeiro e novembro de 1993 e março-novembro de 1994 em uma lagoa costeira no Estado do Rio de Janeiro, Sudeste do Brasil, com o objetivo de identificar as conseqüências ecológicas do processo de eutrofização artificial. Ao todo, 975 larvas de Tanypodinae, Orthocladiinae e Chironominae foram coletadas e Polypedilum (62\%) e Chironomus (58\%) foram os taxa mais comuns nas regiões litorânea e limnética.

Palavras-chave: biodiversidade, eutrofização, Chironomidae, bioindicadores, lagoa costeira.

\section{INTRODUCTION}

Taxonomic diversity (including taxonomic richness and evenness) and biomass are fundamental in describing the structure and distribution of communities (Begon et al., 1996). This information is an important ecological tool for biological studies of pollution level indicators in freshwater ecosystems, in well-balanced monitoring programs involving physical, chemical, and biological measurements.

The Imboassica Lagoon has suffered multiple anthropogenic impacts. Among these are urbanization of its margins; landfills; and frequent and aperiodic openings of the sandbar separating it from the ocean (Faria et al., 1998; Fernandes, 1998; Gonçalves et al., 1998a; Albertoni et al., 1999). The most frequent consequences are predominance of fine particles (silts and clay), increase in organic matter accumulation on the sediment due to enhanced detritus production, and increased production of toxic gases such as $\mathrm{H}_{2} \mathrm{~S}$ and $\mathrm{CH}_{4}$ with consequent decrease in dissolved oxygen concentration at the bottom, near the sediment-water interface (Esteves, 1998; Gonçalves et al., 1998b).

The benthic macroinvertebrate community in Imboassica Lagoon is dominated by Gastropoda 
(Heleobia australis), Polychaeta-Nereidae, and Chironomidae larvae. Together they represent ca. 95\% of the fauna (Callisto et al., 1998b; Gonçalves et al., 1998a). Chironomidae are broadly distributed worldwide and frequently are the most abundant insects in many freshwater ecosystems. Certain species show ecological adaptations, in ecosystems at different trophic levels, to extreme environmental situations related to high temperature, $\mathrm{pH}$, organic matter content in the sediment, and low dissolved oxygen in the water-sediment interface (Cranston, 1995). High diversity of chironomids (estimated at more than 15,000) is better known taxonomically in temperate Northern Hemisphere countries. In the Neotropics, especially Brazil, which is known as a megabiodiversity country (Barbosa et al., 1998; Myers et al., 2000), it is estimated that more than $98 \%$ of the chironomid species are still undescribed. A shortage of specialists and a lack of basic information at the species level, limit taxonomic identification of the genera, especially in ecological studies of immature forms of Brazilian chironomids (Nolte, 1989; Nessimian \& Sanseverino, 1995; Callisto, 1997).

Chironomidae larvae play an important ecological role in the bioturbation process at the sedimentwater interface. In eutrophic environments, they do so in nitrogen remobilization for the primary producers (Fukuhara \& Sakamoto, 1988; Svensson \& Leonardson, 1996; Svensson, 1997). In lacustrine ecosystems, these organisms participate in two webs: (a) by the detritus chain, ingesting organic fragments and associated microorganisms, (b) by the food-web, by eating smaller organisms and being consumed by other insects, alevins, aquatic birds, and benthophagous fishes (Callisto et al., 1996; Branco et al., 1997; Galdean et al., 1997; Aguiaro \& Caramaschi, 1998). Therefore, in lake environments, they are important components needing further study.

The aim of this study was to evaluate the diversity of Chironomidae larvae, their distribution and biomass, and to estimate the impacts of the anthropic eutrophication process on this community, by comparing the littoral (close to an untreated sewage channel) and the limnetic zones of Imboassica Lagoon.

\section{Study area}

Imboassica Lagoon is located in northern Rio de Janeiro State $\left(22^{\circ} 15^{\prime}-22^{\circ} 30^{\prime} \mathrm{S}, 41^{\circ} 30^{\prime}-42^{\circ}\right.$ $05^{\prime} \mathrm{W}$ ), and is separated from the sea by a sand bar approximately 50 meters wide. The lagoon is situated on the coastal plain (restinga) where the climate is an AW type (according to Köppen's classification), with hot and humid characteristics.

Temperatures oscillate between $18.7^{\circ} \mathrm{C}$ and $27.4^{\circ} \mathrm{C}$. This ecosystem is situated in the Macaé County urban zone and has an estimated area of $3.26 \mathrm{~km}^{2}$, with a mean depth of $1.1 \mathrm{~m}$ (Panosso et al., 1998). Littoral zone urbanization and domestic waste discharge are important anthropogenic impacts on the lagoon. Artificial openings through the sandbar cause exchange with marine water, resulting in salinity elevation of $0 \%$ to $35 \%$ (Gonçalves et al., 1998a; Callisto et al., 1998b). The littoral zone is colonized by Typha domingensis (Typhaceae), grasses, Salvinia auriculata (Salvineaceae), and Eichhornia crassipes (Pontederiaceae). The limnetic zone includes large banks of Chara spp. (Characeae).

\section{MATERIALS AND METHODS}

\section{Sampling of chironomids}

Water and sediment samples were collected during January-November 1993 and March-November 1994, in the limnetic and littoral zones (2 meters from a domestic sewage channel). In some months (February, March, and July 1993, June, August, and September 1994 at the littoral zone; January and February 1993, June and July 1994, at the limnetic zone) no samples were taken due to lagoon emptying after sandbar opening.

Sediment and benthic macroinvertebrates samples were collected using a "corer" sampler (modified from Ambühl \& Bührer, 1975), with 8 $\mathrm{cm}$ diameter. The studied fraction was $0-10 \mathrm{~cm}$.

Five samples were collected from each sampling station $\left(0.025 \mathrm{~m}^{2}\right.$ in total area). In the laboratory, sediment samples were washed in two sieves (1.00 and $0.50 \mathrm{~mm}$ mesh) and sorted under a stereomicroscope.

Chironomidae larvae were mounted in lactophenol solution $10 \%$ and identified under the microscope, using 400x magnification. The sampled individuals are deposited in the Benthic Macroinvertebrate Collection of the Laboratory of Ecology of Benthos, Institute of Biological Sciences, Federal University of Minas Gerais, following methodology described in Callisto et al. (1998a). 


\section{Data analysis}

For larval biomass calculation, the log-linear equation was used: $\ln \mathrm{W}=\ln a+b \ln l$.

We used the equations proposed by Smock (1980), Sephton \& Paterson (1986), and Nolte (1990):

- Polypedilum:

$\ln a=-7.308$ and $b=2.603 \mathrm{r}=0.964$

- Other Chironominae and Orthocladiinae: $\ln a=-5.279$ and $b=2.32 \mathrm{r}=0.94$

- Tanypodinae: $\ln a=-5.573$ and $b=2.603 \mathrm{r}=0.92$

\section{RESULTS}

Eleven taxa of chironomids in the littoral zone, and fourteen taxa in the limnetic zone were found in Imboassica Lagoon (Table 1).

Among the taxa found in the littoral zone, larvae of the genus Chironomus represented 58\% of the fauna, followed by Polypedilum (27\%), and Tanypus $(7 \%)$.

The maximum densities were found in June, August, and September 1993, and February 1994. In the limnetic zone, Polypedilum larvae represented $62 \%$ of the fauna, followed by Ablabesmyia (3\%), and Goeldichironomus (2\%). Maximum densities were found in May and July 1993.

Biomass value distribution followed the pattern observed for density values. In the littoral zone, Chironomus larvae represented $70 \%$ to $100 \%$ of the organism biomass, except in March 1994, when Polypedilum larvae reached maximum values (approximately $70 \%$ ). As for genera richness, a different variation was observed while comparing the two sampling stations.

Tanypodinae larvae, predominantly carnivorous, were scarce throughout this study. All larvae were small. In the littoral zone, Chironomus larvae presented almost uniform body size distribution among the studied size-classes (Table 2).

TABLE 1

Composition and density (ind $/ \mathrm{m}^{2}$ ) of the larvae of Chironomidae in the littoral and limnetic zones of the Imboassica Lagoon.

\begin{tabular}{|c|c|c|}
\hline Taxa & Littoral & Limnetic \\
\hline Tanypodinae & & 176 \\
\hline Ablabesmyia & 22 & 20 \\
\hline Djalmabatista & - & 40 \\
\hline Labrundinia & 22 & - \\
\hline Tanypus & 168 & 65 \\
\hline Orthocladiinae & & 34 \\
\hline Cricotopus & - & 34 \\
\hline Nanocladius & - & 34 \\
\hline Chironominae & - & 1448 \\
\hline Asheum & - & 56 \\
\hline Beardius & 1448 & 128 \\
\hline Chironomus & 22 & 24 \\
\hline Cladopelma & 22 & 16 \\
\hline Goeldichironomus & 22 & 16 \\
\hline Harnischia & 22 & - \\
\hline Nimbocera paulensis & 22 & 3560 \\
\hline Parachironomus & 22 & $\mathbf{5 6 5 1}$ \\
\hline Paracladopelma & 696 & \\
\hline Polypedilum & $\mathbf{2 4 8 8}$ & \\
\hline & & \\
\hline Total & & \\
\hline & & \\
\hline & & \\
\hline & & \\
\hline
\end{tabular}




\begin{tabular}{|c|c|c|c|c|c|c|c|c|c|c|c|c|c|c|c|c|}
\hline & & $\stackrel{\mathscr{\Xi}}{0}$ & & 1 & 1 & తి & & 1 & 1 & 1 & 1 & 1 & 1 & 1 & 1 & $\stackrel{\widetilde{m}}{\stackrel{2}{2}}$ \\
\hline & & $\vec{z}$ & & 1 & 1 & $\stackrel{\infty}{+\infty}$ & & $\stackrel{\vec{m}}{r}$ & 1 & 1 & 1 & 1 & 1 & 1 & I & r \\
\hline & & $\overline{\tilde{o}}$ & & 1 & 1 & İ & & ờ & 1 & 1 & 1 & 1 & 1 & 1 & I & $\stackrel{?}{\mathscr{s}}$ \\
\hline & & $\Xi$ & & 1 & 1 & 1 & & $\begin{array}{l}\tilde{S} \\
\stackrel{0}{\circ}\end{array}$ & 1 & : & 1 & 1 & 1 & 1 & I & $\stackrel{7}{-}$ \\
\hline & 亏े & $\sum^{\mathrm{E}}$ & & 1 & 1 & 1 & & $\begin{array}{l}\text { aे } \\
\text { in }\end{array}$ & 1 & 1 & 1 & 1 & 1 & 1 & 1 & 章 \\
\hline 弄 & & $\grave{\frac{a}{4}}$ & & 1 & 1 & $\frac{\pi}{0}$ & & त्र & 1 & 1 & 1 & 1 & 1 & 1 & 足 & 离 \\
\hline & & $\dot{\bar{\varpi}}$ & & 1 & 1 & 1 & & $\stackrel{n}{0}$ & $\begin{array}{l}\infty \\
\stackrel{1}{0} \\
0\end{array}$ & 1 & 1 & 1 & 1 & 1 & $\frac{5}{5}$ & $\fallingdotseq$ \\
\hline & & : & & 1 & 1 & 1 & & $\stackrel{n}{a}$ & $\begin{array}{l}2 \\
0 \\
0 \\
0\end{array}$ & 1 & 1 & 1 & 1 & 1 & $\stackrel{\infty}{0}$ & $\stackrel{\infty}{\mathscr{m}}$ \\
\hline 产 & & 胥 & & 1 & 1 & f̊ & & $\stackrel{0}{\circ}$ & $=$ & 1 & 1 & 1 & 1 & 1 & ปี & ○े \\
\hline 范 & & $\stackrel{\mathscr{\Xi}}{0}$ & & 1 & 1 & ป̂. & & ले & 1 & 1 & 1 & 1 & 1 & I & न & $\stackrel{F}{F}$ \\
\hline 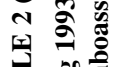 & & $\stackrel{a}{z}$ & & 1 & 1 & 1 & & $\begin{array}{l}\infty \\
\vdots \\
i \\
i\end{array}$ & సे & 1 & 1 & 1 & 1 & I & $\stackrel{8}{0}$ & $\stackrel{m}{\ddot{n}}$ \\
\hline 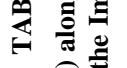 & & $\overline{\tilde{o}}$ & & 1 & 1 & $\bar{\sigma}$ & & $\underset{\infty}{\stackrel{m}{\infty}}$ & $\stackrel{\infty}{0}$ & 1 & 1 & 1 & 1 & 1 & I & รั? \\
\hline 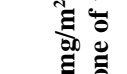 & & ڤેे & & 1 & 1 & ?. & & 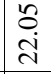 & 1 & 1 & 1 & 1 & 1 & 1 & ठ․ & 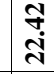 \\
\hline$\stackrel{n}{:}$ & ڤั & 些 & & 1 & $\frac{ \pm}{0}$ & 1 & & $\stackrel{\vec{n}}{\stackrel{\Delta}{\lambda}}$ & 1 & o & 1 & $\stackrel{5}{0}$ & $\frac{1}{0}$ & I & $\stackrel{n}{0}$ & लि \\
\hline 竞 & & $\Xi$ & & 1 & $\begin{array}{l}n \\
\tilde{0} \\
0\end{array}$ & 官 & & $\begin{array}{l}5 \\
\dot{m} \\
\dot{m}\end{array}$ & $\ddot{2}$ & 1 & $\begin{array}{l}\infty \\
0 \\
0 \\
0\end{array}$ & 1 & 1 & $\begin{array}{l}0 \\
0 \\
0\end{array}$ & I & $\frac{\infty}{\infty}$ \\
\hline$\frac{0}{0}$ & & $\sum^{\mathrm{E}}$ & & İ & $\begin{array}{l}0 \\
0 \\
0\end{array}$ & 1 & & 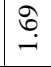 & 1 & 1 & 1 & 1 & 1 & 1 & 1 & $\stackrel{\vec{i}}{i}$ \\
\hline हี & & $\grave{\frac{a}{4}}$ & & 1 & 1 & 1 & & $\begin{array}{l}\widetilde{\infty} \\
\stackrel{0}{0}\end{array}$ & 1 & 1 & $\begin{array}{l}\infty \\
0 \\
0\end{array}$ & 1 & 1 & 1 & I & ริ \\
\hline & & $\stackrel{\Xi}{\tilde{\Xi}}$ & & 1 & 1 & 1 & & 1 & 1 & 1 & 1 & 1 & 1 & 1 & $\stackrel{\overbrace{}}{\delta}$ & $\stackrel{\overbrace{}}{\stackrel{8}{\circ}}$ \\
\hline & & 莯 & 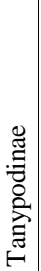 & 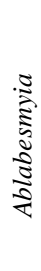 & 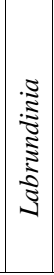 & $\begin{array}{l}\mathcal{E} \\
\text { है } \\
\text { है }\end{array}$ & 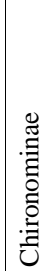 & 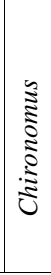 & 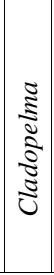 & 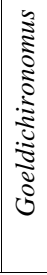 & 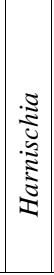 & 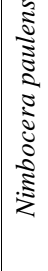 & 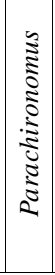 & 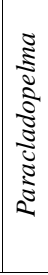 & 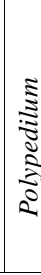 & 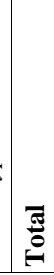 \\
\hline
\end{tabular}




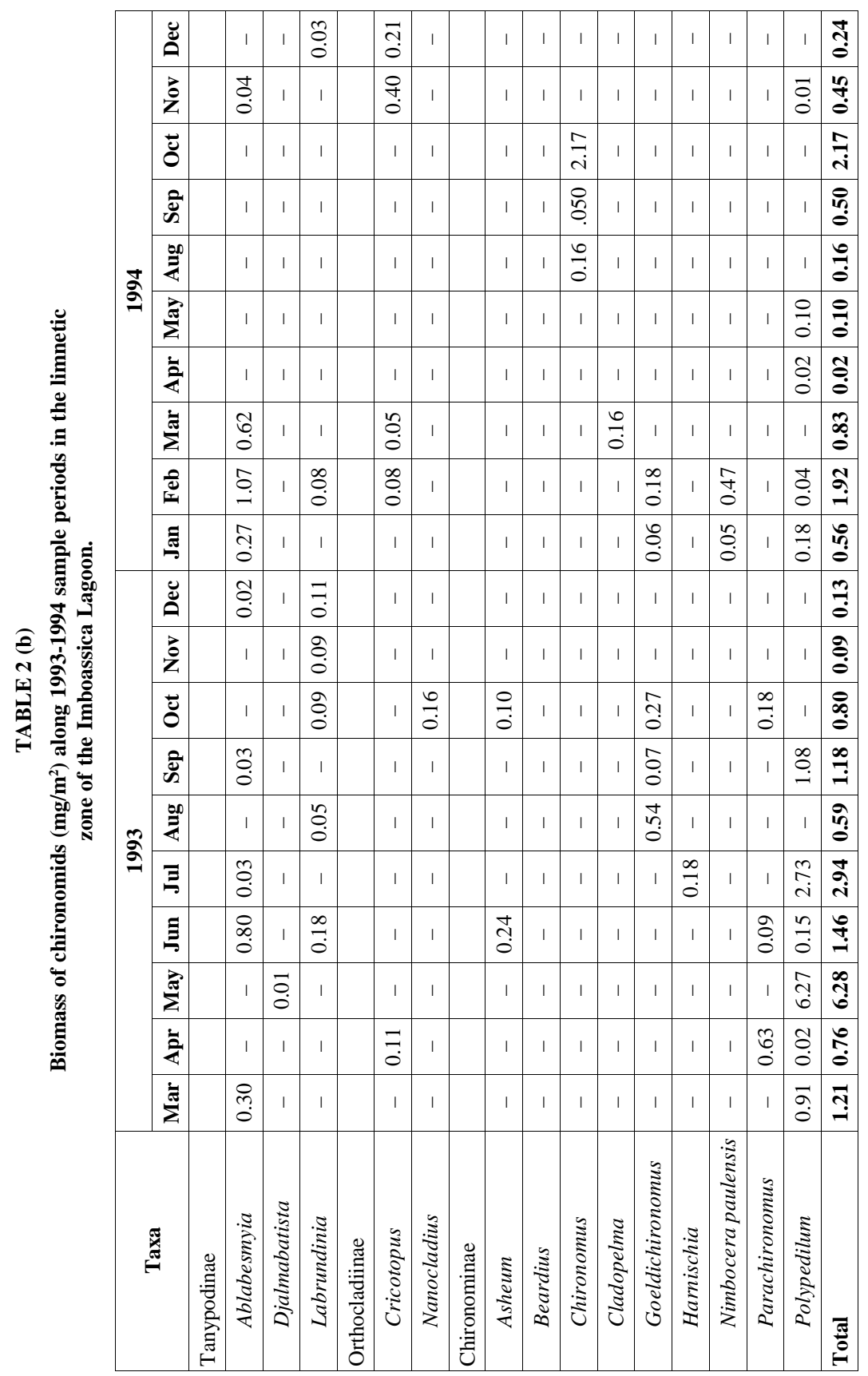


On the other hand, in the limnetic zone the majority of Polypedilum larvae showed body size reduction (smaller than $0.3 \mathrm{~mm}$ ).

\section{DISCUSSION}

The biomass distribution data can be related to two different situations. The first might be that the larvae were not developing a body size larger than $0.3 \mathrm{~mm}$, probably due to selective predator pressure (Tanypodinae larvae with other chironomids in the gut content, benthophagous fishes, and alevins). The second might be related to intrinsic species aspects with Polypedilum present in this lagoon area. Larvae of some Polypedilum species might naturally have small body-size. Imboassica Lagoon offers a great diversity of trophic resources, such as aquatic macrophytes, periphyton, plant detritus (notably in the littoral zone), and fine particulate organic matter (Furtado et al., 1997). The high organic matter content in the sediment suggests food limitation neither for Chironomus larvae nor for Polypedilum in the littoral and limnetic zones, respectively.

Tanypodinae are located at the top of the food web in benthic communities. The abundance of Tanypodinae is regulated directly by available food items (which may be other Chironomidae larvae, Rotifera, Protozoa, Oligochaeta, etc.) (Epler, 1995).

The high abundance of Chironomus and Polypedilum larvae, predominantly detritivorous, is probably related to the high abundance of organic detritus in the Imboassica Lagoon sediment, as is corroborated by the high content of total and dissolved nutrients in the water and great concentrations in the sediment (Petrucio \& Furtado, 1998; Furtado et al., 1997), a typical situation in lacustrine ecosystems subjected to artificial eutrophication.

Some Chironomus and Polypedilum larvae (about $5 \%$ of the studied material) found presented deformities on mouth parts (mentum). Several studies have shown the relationship between the occurrence of structural deformities in Chironomidae larvae and degraded environmental conditions, resulting from contamination by heavy metals, herbicides, fungicides, and insecticides (Dermott, 1991; Warwick, 1985). According to Janssens De Bisthoven et al. (1992), these deformities can be interpreted as a sign of sublethal pollutant concentrations which in the Imboassica Lagoon would probably be related to domestic sewage release and even to heavy metal presence. Deformities have been used in environmental impact evaluation studies on freshwater ecosystems (Janssens De Bisthoven et al., 1998; Diggins \& Stewart, 1998), and suggested as a biological parameter to be included in long-term water-quality monitoring programs (Callisto et al., 2000).

The results obtained in this research showed that anthropic eutrophication in the Imboassica Lagoon has influenced the structure of the benthic community (prevalence of detritivorous organisms, such as Chironomus and Polypedilum), resulting in high biomass and low taxonomic diversity, when compared to other studies developed on coastal ecosystems in Rio de Janeiro State (Nessimian, 1995; Nessimian \& Sanseverino, 1995). We believe that this information can be useful in making more evident to local communities and politicians the urgent need for measures to minimize the anthropic impacts observed in Imboassica Lagoon.

Ecological information on coastal lagoons subject to anthropic influence is necessary in these areas to define and limit human activities, as well as for establishing the management techniques to be applied in the future. In the Imboassica Lagoon case, new studies should be developed to define species composition and benthic community structures (and their functional role), to better characterize habitats and evaluate impact levels and subsequent aquatic biodiversity loss. Moreover, such results supply fundamental information on the diversity and biomass of one of the benthic macroinvertebrate main groups, besides suggesting their role as environmental quality bioindicators.

Acknowledgments - Most special thanks to Professor Francisco A. R. Barbosa, Dr. Claudia Jacobi, and Dr. Geraldo Wilson Fernandes for their valuable comments on a previous manuscript draft. We are also indebted to our colleagues from the Laboratório de Limnologia/UFRJ for valuable help with the samples, and to those from the Laboratório de Limnologia/ Ecologia de Benthos/UFMG for the identification phase and biomass evaluation. Financial support was received from PETROBRAS and CNPq.

\section{REFERENCES}

ALBERTONI, E. F., PALMA-SILVA, C. \& ESTEVES, F. A. 1999, Larvae and post-larvae of Penaeidae and Palaemonidae in coastal lagoons in the north of Rio de Janeiro (Macaé, RJ). Rev. Brasil. Biol., 59: 109-117. 
AMBÜHL, H. \& BÜHRER, H., 1975, Zur Technik der Entnahme ungestörter Gossproben von Seesedimenten: ein verbessertes Bohrlot. Schweiz Z. Hydrol., 37: 175-186.

AGUIARO, T. \& CARAMASCHI, E. P., 1998, Trophic guilds in fish assemblages in three coastal lagoons of Rio de Janeiro State (Brazil). Verh. Internat. Verein. Limnol., 26: 2166-2169.

BARBOSA, F. A. R., FONSECA, G. A. B., CAVALCANTI, R. B. \& FONSECA, M. T., 1998, The Brazilian long term ecological research program - present status and perspectives. In: US LTER Network. The international long term ecological research network. University of New Mexico, USA, pp. 7-13.

BRANCO, C. W. C., Aguiaro, T., ESteVES, F. A. \& CARAMASCHI, E. P., 1997, Food sources of the Teleost Eucinostomus argenteus in two coastal lagoons of Brazil. Stud. Neotrop. Fauna \& Environm., 32: 33-40.

BEGON, M., HARPER, J. L. \& TOWNSEND, C. R., 1996 , Ecology: individuals, populations and communities. Blackwell Science, New York, $3^{\text {th }}$ Edition, 1068p.

CALLISTO, M., 1997, Larvas bentônicas de Chironomidae (Diptera: Insecta) em quatro ecossistemas lóticos amazônicos sob influência das atividades de uma mineração de bauxita. AN VIII SEM. REG. ECOL., 8: 89-98.

CALLISTO, M., SERPA-FILHO, A., DE OLIVEIRA, S. J. \& ESTEVES, F. A., 1996, Chironomids on leaves of Typha domingensis in a lagoon of Rio de Janeiro State (Brazil). Stud. Neotrop. Fauna \& Environm., 31: 51-53.

CALlisto, M., BARBOSA, F. A. R. \& VIANNA, J. A., 1998a, Qual a importância de uma coleção científica de organismos aquáticos em um projeto de biodiversidade? AN. IV SIMP. ECOS. BRASIL., 2: 432-439.

CALLISTO, M., GONÇALVES, J. F. Jr., FONSECA, J. J. L. \& PETRUCIO, M. M., 1998b, Macroinvertebrados bentônicos nas lagoas Imboassica, Cabiúnas e Comprida. In: F. A. Esteves (ed.), Ecologia das lagoas costeiras do Parque Nacional da Restinga de Jurubatiba e do Municipio de Macaé (RJ). Rio de Janeiro, pp. 283-298.

CALlisto, M., MARQues, M. M. \& BARBosA, F. A. R., 2000, Deformities in larval Chironomus (Diptera, Insecta) from the Piracicaba river, southeast Brazil. Verh. Internat. Verein. Limnol., 27(5): 2699-2702.

CRANSTON, P. S., 1995, Introduction to the Chironomidae. In: P. Armitage, P. S. Cranston \& C. V. Pinder (eds.), The Chironomidae: the biology and ecology of non-biting midges. Chapman \& Hall, New York, pp. 1-7.

DERMOTT, R. M., 1991, Deformities in larval Procladius spp. and dominant Chironomini from the St. Clair River. $H y$ drobiologia, 219: 171-185.

DIGGINS, T. P. \& STEWART, K. M., 1998, Chironomid deformities, benthic community composition, and trace elements in the Buffalo River (New York) Area of Concern. J. N. Am. Benthol. Soc., 17: 311-323.
EPLER, J. H., 1995, Identification manual for the larval Chironomidae (Diptera) of Florida. Department of Environmental Regulation, State of Florida, 427p

ESTEVES, F. A., 1998, Fundamentos de Limmnologia. Interciência/Finep, Rio de Janeiro, 604p.

FARIA, B. M., SUZUKI, M. S., PETRUCIO, M. M. \& PRAST, A. E., 1998, Changes in the metabolism of a Brazilian lagoon related to man-made marine entrances. Verh. Internat. Verein. Limnol., 26: 1442-1444.

FERNANDES, V. O., 1998, Variations in dry weight, organic matter and chlorophyll $a$ of the periphytic community in Imboassica lagoon, Rio de Janeiro, RJ, Brazil. Verh. Internat. Verein. Limnol., 26: 1445-1447.

FUKUHARA, H. \& SAKAMOTO, M., 1988, Ecological significance of bioturbation of zoobenthos community in nitrogen release from bottom sediments in a shallow eutrophic lake. Arch. Hydrobiol., 113: 425-445.

FURTADO, A. L. S., PETRUCIO, M. M. \& ESTEVES, F. A., 1997, C, N, P and pheopigments in the sediment of a brazilian coastal lagoon, Macaé, Rio de Janeiro. Rev. Brasil. Biol., 57: 127-134.

GALDEAN, N., NALBANT, T. \& DRAGOMIRESCU, L., 1997, The food and feeding habitats of the sculpinperch or Romanian Darter Romanichthys valsanicola (Pisces: Perciformes: Percidae). Trav. Mus. Natl. Hist. Nat. “Grigore Antipa", 37: 287-295.

GONÇALVES, J. F. Jr., FONSECA, J. J. L. \& CALLISTO, M., 1998a, Population dynamic of Heleobia australis (Gastropoda) in a coastal lagoon (Rio de Janeiro, Brazil). Verh. Internat. Verein. Limnol., 26: 2056-2057.

GONÇALVES, J. F. Jr., CALliSTO, M. \& LEAL, J. J. F., 1998b, Relações entre a composição granulométrica do sedimento e as comunidades de macroinvertebrados bentônicos nas lagoas Imboassica, Cabiúnas e Comprida. In: F. A. Esteves (ed.), Ecologia das lagoas costeiras do Parque Nacional da Restinga de Jurubatiba e do Município de Macaé (RJ). Rio de Janeiro, pp. 299-309.

JANSSENS DE BISTHOVEN, L. G., TIMMERMANS, K. R. \& OLLEVIER, F., 1992, The concentration of cadmium, lead, copper and zinc in Chironomus gr. thummi larvae (Diptera, Chironomidae) with deformed versus normal menta. Hydrobiologia, 239: 141-149.

JANSSENS DE BISTHOVEN, L., NUYTS, P., GODDEERIS, B. \& OLLEVIER, F., 1998, Sublethal parameters in morphologically deformed Chironomus larvae: clues to understanding their bioindicator value. Freshwater Biology, 39: 179-191.

MYERS, N., MITTERMEIER, R. A., MITTERMEIER C. G., FONSECA, G. A. B. \& KENT, J., 2000, Biodiversity hotspots for conservation priorities. Nature, 403: 853-858.

NESSIMIAN, J. L., 1995, Composição da fauna de invertebrados bentônicos em um brejo entre dunas no litoral do Estado do Rio de Janeiro, Brasil. Acta Limnol. Brasil., 7: 41-59. 
NESSIMIAN, J. L. \& SANSEVERINO, A. M., 1995, Structure and dynamics of chironomid fauna from a sand dune marsh in Rio de Janeiro State, Brazil. Stud. Neotrop. Fauna \& Environm., 30: 207-219.

NOLTE, U., 1989, Observations on neotropical rainpools (Bolivia) with emphasis on Chironomidae (Diptera). Stud. Neotrop. Fauna \& Environm., 24: 105-120.

NOLTE, U., 1990, Chironomid biomass determination from larval shape. Freshwater Biology, 24: 443-451.

PANOSSO, R. F., ATTAYDE, J. L. \& MUEHE, D., 1998, Morfometria das lagoas Imboassica, Cabiúnas, Comprida e Carapebus: implicações para seu funcionamento e manejo. In: F. A. Esteves (ed.), Ecologia das lagoas costeiras do Parque Nacional da Restinga de Jurubatiba e do Município de Macaé (RJ). Rio de Janeiro, pp. 91-108.

PETRUCIO, M. M. \& FURTADO, A. L. S., 1998, Concentrações de nitrogênio e fósforo da coluna d'água da lagoa Imboassica. In: F. A. Esteves (ed.), Ecologia das lagoas costeiras do Parque Nacional da Restinga de Jurubatiba e do Município de Macaé (RJ). Rio de Janeiro, pp. 123134.
SEPHTON, T. W. \& PATERSON, C. G., 1986, Production of the chironomid Procladius bellus in an annual drawdown reservoir. Freshwater Biology, 16: 721-733.

SMOCK, L. A., 1980, Relationships between body size and biomass of aquatic insects. Freshwater Biology, 10: $375-$ 383 .

SVENSSON, J. M., 1997, Influence of Chironomus plumosos larvae on ammonium flux and denitrification (measured by the acetylene blockage- and the isotope pairing-technique) in eutrophic lake sediment. Hydrobiologia, 346: 157-168.

SVENSSON, J. M. \& LEONARDSON, L., 1996, Effects of bioturbation by tube-dwelling chironomid larvae on oxygen uptake and denitrification in eutrophic lake sediments. Freshwater Biology, 35: 289-300.

WARWICK, W. F., 1985, Morphological abnormalities in Chironomidae (Diptera) larvae as measures of toxic stress in freshwater ecosystems: indexing antennal deformities in Chironomus Meigen. Can. J. Fish. Aquat. Sci., 42: 1881-1884. 